\title{
DOES SUBINHIBITORY CONCENTRATIONS OF CLINICALLY IMPORTANT ANTIBIOTIC INDUCE BIOFILM PRODUCTION OF ENTEROCOCCUS FAECIUM STRAINS?
}

\author{
Fatma Neslihan Yuksel, Neslihan Taskale Karatug and \\ MUSTAFA AKCELIK* \\ Department of Biology, Faculty of Science, Ankara University, Ankara, Turkey
}

(Received: 11 April 2017; accepted: 7 August 2017)

\begin{abstract}
Biofilm structures are the most resistant form of active microorganisms against sanitation, disinfection, and sterilization processes. One of the specific properties of biofilm is the development of antibiotic resistance that can be up to 1,000-fold greater than planktonic cells. Enterococcus faecium is a human pathogen that causes nosocomial bacteremia and at the present time, it is well known that most of the chronic infections are biofilm-based. Recent evidence suggested that subinhibitory concentrations (sub-MICs) of antibiotics have an important role in the evolution of antibiotic resistance and induction on biofilm formation. Based on this information, we aimed to determine the effect of subinhibitory antibiotic concentrations on biofilm formation and the role of the antibiotic concentrations on the enterococcal surface protein gene (esp). To determine the impact of clinically important antibiotics on biofilm production, crystal violet assay was used. Then, the effect of sub-MICs of antibiotics on the expression of the esp gene was investigated by quantitative real-time PCR. Biofilm production assays show that MIC/2 of erythromycin (ERT; $512 \mu \mathrm{g} / \mathrm{ml}$ ), MIC/32 of vancomycin (VAN; $16 \mu \mathrm{g} / \mathrm{ml}$ ), MIC/64 of streptomycin (STR; $32 \mu \mathrm{g} / \mathrm{ml}$ ), and $\mathrm{MIC} / 128$ of kanamycin (KAN; $4 \mu \mathrm{g} / \mathrm{ml}$ ) values induce maximum biofilm production compared with the control. According to q-PCR results, sub-MIC values of ERT, VAN, and STR antibiotics were found to enhance esp gene expression. In addition, despite the increasing biofilm production after KAN treatment, the antibiotic was not effective on the esp expression.
\end{abstract}

Keywords: Enterococcus faecium, sub-MIC, biofilm formation, esp gene, quantitative real-time PCR

*Corresponding author; E-mail: akcelik@science.ankara.edu.tr 


\section{Introduction}

Antibiotics target essential bacterial structures, such as cell wall and cellular pathways including DNA, RNA, and protein synthesis mechanism. They have been used to treat several infectious diseases. The long-term use of antibiotics in recent years has resulted in appearance of multidrug-resistant (MDR) bacterial pathogens, such as Enterococci $[1,2]$.

Enterococci, known as opportunistic pathogens, are naturally found in intestinal microflora and oral cavity of humans and animals. Two most common Enterococcus species (Enterococcus faecalis and Enterococcus faecium) are capable of producing biofilms, which are bacterial communities attached to a biotic or an abiotic substrate encased in a matrix. E. faecium is an important global cause of biofilm-related infections. Biofilms are dependent on multiple genetic factors, such as esp, gelE, and $f s r$ locus [3, 4]. Cell wall-associated protein implicated in biofilm formation is an enterococcal surface protein (Esp) coded by esp gene. It was first identified in E. faecalis as a large surface-anchored protein from infection-derived isolates [5]. An esp homologue has been identified in E. faecium and this gene is localized on pathogenicity islands in both species [6-8]. Studies suggested that there was a strong correlation between esp and the forming of biofilms. Toledo-Arana et al. [9] reported that $93.5 \%$ of esp-positive isolates could form biofilms on polystyrene, whereas none of the esp-negative isolates could produce biofilms. The investigators suggested that the $\mathrm{N}$-terminal domain of Esp is sufficient for biofilm production, mutation on the N-terminal domain region of Esp in E. faecalis strain causes less biofilm production [10]. The esp-positive strains were also identified as strong biofilm producers compared with esp-negative isolates $[11,12]$. In addition to that, researchers presented that presence of a higher glucose concentration in the growth medium-regulated biofilm production [12-14]. In spite of that, other studies suggested that there was no association between the presence of esp and biofilm-forming ability and the esp gene was not necessary for the production of biofilm in E. faecalis and E. faecium [15-18]. While some studies showed that esp is a certain factor for biofilm formation, others presented that biofilm production needs other necessary factors with esp.

Recent studies suggested that sub-MICs of antibiotics acted as signaling molecules mediating variety of cell processes, such as gene transcription and expression, quorum sensing, inter- or intra-species communication, and biofilm formation [19-23]. In addition, low concentrations of antibiotics may stimulate different stress responses that might enable horizontal transfer of antibiotic resistance genes among bacterial communities, which are found on biofilm [23-26]. 
Studies showed that some using antibiotic concentrations below the MIC can significantly induce biofilm formation in a variety of Gram-positive and Gramnegative bacterial species. Subinhibitory concentration of an aminoglycoside antibiotic tobramycin induced biofilm formation in Pseudomonas aeruginosa and Escherichia coli [27]. Similarly, gentamicin (GEN) (>64 mg/ml, $2 \times \mathrm{MIC})$ and tetracycline ( $>128 \mathrm{mg} / \mathrm{ml}, 4 \times$ MIC) were determined as the most effective antibiotics against Salmonella Infantis biofilm formation; however, biofilm structure was induced with sub-MICs of nalidixic acid, spectinomycin, tetracycline, and neomycin antibiotics treatment [28]. Balaji et al. [29] proved that 1/16 MIC value of fluoroquinolones increased biofilm formation, whereas $1 / 2 \mathrm{MIC}$ value of them occurred inhibition effect on clinical isolates of Streptococcus pyogenes biofilm. The proof presented that inhibition and biofilm formation were dosedependent [29]. Previous studies showed that sub-MIC amoxicillin antibiotic levels induce methicillin-resistant Staphylococcus aureus biofilm and this biofilm was thicker, contained more pillar and channel structures compared with the control [30]. Kafil et al. [31] investigated the effects of ampicillin (AMP), vancomycin (VAN), GEN, and ceftizoxime antibiotics on biofilm formation and gene expression of colonization factors, such as $E$. faecalis antigen A gene (efaA), aggregation substance gene (asal), endocarditis and biofilm-associated pilli gene $(e b p A)$, esp, and collagen adhesin gene (ace), in E. faecalis. They found that AMP, VAN, and ceftizoxime did not have any significant effect on biofilm formation while GEN induced biofilm formation. And also for 12 strains, GEN, VAN, and AMP increased expression of esp in the ratio of $50.9 \%, 89.1 \%, 131 \%$, respectively, by contrast, ceftizoxime reduced expression of esp (35\%) [31]. One of the most important goals in clinical microbiology is to prevent biofilm-associated infections. However, strategies for the treatment of biofilm-related infections should not be according to antibiotic concentrations that are effective only against to planktonic cells. Currently, very little is known about the mechanism of antibiotic induced biofilm formation in genus Enterococcus. This study aims that quantifying the use of low concentrations of antibiotics induces enterococcal biofilm formation and biofilm-related gene expression.

\section{Material and Methods}

\section{Bacterial isolates and culture conditions}

Two biofilm producer E. faecium strains, isolated from rectal sample, were selected for this research. E. faecalis OG1RF was used as biofilm producer control 
strain. All strains were obtained from Prokaryote Genetic Laboratory Culture Collection of Ankara University (Ankara, Turkey). Glycerol stock cultures were activated in Tryptic Soy Broth (TSB, Merck, Germany) for overnight (18 h) at $37^{\circ} \mathrm{C}$.

\section{Determination of minimum inhibitory concentration (MIC)}

The MIC values of antibiotics were determined by the Clinical and Laboratory Standards Institute broth microdilution method using Mueller-Hinton Broth (Oxoid, UK). The strains were treated with clinically important antibiotics, which are commonly used for the treatment of Enterococcus infections (Table I). E. faecalis ATCC 29212 was used as the control strain and each experiment was performed in duplicate.

Effect of subinhibitory concentrations (sub-MICs) of antibiotics on enterococcal biofilm formation

To determine induction of antibiotics on biofilm production level of E. faecium isolate, chloramphenicol (CHL), kanamycin (KAN), erythromycin (ERT), AMP, VAN, streptomycin (STR), and GEN antibiotics were selected. A method described by Extremina et al. [32] and Baldassarri et al. [33] was used to test the microorganisms for biofilm formation with minor modifications. The serial twofold dilution of the antibiotics (from $\mathrm{MIC} / 2$ to $\mathrm{MIC} / 128), 10^{7} \mathrm{CFU} / \mathrm{ml}\left(\mathrm{OD}_{595}=0.07\right.$ ) overnight in E. faecium culture, and TSB supplemented with $1 \%$ glucose were added to 96 well plates and incubated at $37^{\circ} \mathrm{C}$ for $48 \mathrm{~h}$. Negative control was only test broth, and positive control was only bacteria. After $48 \mathrm{~h}$ growth at $37{ }^{\circ} \mathrm{C}$, the plates were gently washed thrice with phosphate buffered saline. The plates were allowed to dry

Table I. Antibiotic resistance phenotypes and MIC values of the strains

\begin{tabular}{lccccccc}
\hline Strain & $\begin{array}{c}\text { VAN } \\
(\mu \mathrm{g} / \mathrm{ml})\end{array}$ & $\begin{array}{c}\text { AMP } \\
(\mu \mathrm{g} / \mathrm{ml})\end{array}$ & $\begin{array}{c}\text { ERT } \\
(\mu \mathrm{g} / \mathrm{ml})\end{array}$ & $\begin{array}{c}\text { KAN } \\
(\mu \mathrm{g} / \mathrm{ml})\end{array}$ & $\begin{array}{c}\text { CHL } \\
(\mu \mathrm{g} / \mathrm{ml})\end{array}$ & $\begin{array}{c}\text { GEN } \\
(\mu \mathrm{g} / \mathrm{ml})\end{array}$ & $\begin{array}{c}\text { STR } \\
(\mu \mathrm{g} / \mathrm{ml})\end{array}$ \\
\hline $\begin{array}{l}\text { E. faecium 84 } \\
\text { E. faecium 95 }\end{array}$ & $\mathrm{R}, 512$ & $\mathrm{R}, 4096$ & $\mathrm{R}, 512$ & $\mathrm{R}, 4096$ & $\mathrm{R}, 256$ & $\mathrm{~S}$ & $\mathrm{R}, 2048$ \\
$\begin{array}{l}\text { E. faecalis } \\
\text { OG1RF }\end{array}$ & $\mathrm{S}$ & $\mathrm{R}, 2048$ & $\mathrm{I}, 4$ & $\mathrm{R}, 256$ & $\mathrm{R}, 64$ & $\mathrm{R}, 128$ & $\mathrm{R}, 512$ \\
$\begin{array}{l}\text { E. faecalis } \\
\text { ATCC29212 }\end{array}$ & $\mathrm{S}$ & $\mathrm{R}, 4096$ & $\mathrm{R}, 1024$ & $\mathrm{R}, 512$ & $\mathrm{R}, 512$ & $\mathrm{R}, 2048$ & $\mathrm{R}, 2048$ \\
\hline
\end{tabular}

Note: AMP: ampicillin; GEN: gentamicin; KAN: kanamycin; STR: streptomycin; CHL: chloramphenicol; ERT: erythromycin; VAN: vancomycin; R: resistance; I: intermediate-level resistance; S: susceptible; MIC: minimum inhibitory concentration. 
for $1 \mathrm{~h}$ at $60{ }^{\circ} \mathrm{C}$ and then fixed using methanol (95\%). For biofilm quantification, $200 \mu \mathrm{l}$ of $1 \%$ crystal violet (CV) solution was added to each well and the plates were allowed to stand for $30 \mathrm{~min}$. The wells were subsequently washed thrice with steriled $\mathrm{H}_{2} \mathrm{O}$ to wash off the excess CV. CV bounded to the biofilm was extracted with $200 \mu \mathrm{l}$ of ethanol-acetone $(80 / 20 \% \mathrm{v} / \mathrm{v})$ and the absorbance of the extracted CV was measured at $595 \mathrm{~nm}$ on ELISA Reader (ThermoScientific, Multiskan Go, USA).

Determination of esp gene expression by quantitative real-time PCR assay

Statistically significant sub-MIC antibiotic values leading to biofilm formation in E. faecium 95 were selected for esp gene expression experiments. Antibioticinduced total RNA of clinical E. faecium 95 strain was extracted using Promega RNA Isolation kit (Promega, USA). RNA concentrations were measured by NanoDrop 2000 (ThermoScientific, USA). cDNA synthesis was carried out using Transcriptor First Strand cDNA Synthesis Kit (Roche, Switzerland). Quantitative real-time PCR was done by esp primers; esp-F 5'TGGTGATGGAAACCCTGACGA-3', and esp-R 5'-TTGCGCTTTGTGACCTGTTCC-3' [34]. The q-PCR assay was performed in Roche Light Cycler ${ }^{\circledR} 480$ II (Roche, Switzerland). The q-PCR amplifications were performed in $10 \mu \mathrm{l}$ reactions containing $1 \times$ Hot FirePol $^{\circledR}$ EvaGreen ${ }^{\circledR}$ qPCR master mix (Solis BioDyne, Esthonia), which includes Hot FirePol ${ }^{\circledR}$ DNA Polymerase, EvaGreen ${ }^{\mathbb{B}}$ qPCR Buffer, $2.5 \mathrm{mM} \mathrm{MgCl}$, ultrapure dNTPs, EvaGreen ${ }^{\mathbb{B}}$ dye and RNase-free $\mathrm{H}_{2} \mathrm{O}, 0.5$ pmol each primer, and $1 \mu \mathrm{l}$ of the respective template cDNA dilution. The q-PCR assay was optimized to the initial activation step of $95{ }^{\circ} \mathrm{C}$ for $15 \mathrm{~min}$, followed by 40 cycles of denaturation at $95^{\circ} \mathrm{C}$ for $15 \mathrm{~s}$, annealing at $62^{\circ} \mathrm{C}$ for $20 \mathrm{~s}$ for all the studied genes, extension at $72{ }^{\circ} \mathrm{C}$ for $20 \mathrm{~s}$. All experiments were performed in triplicate. The threshold cycle $(\mathrm{Ct})$ of each well and data acquisition were carried out using a software program from Real-Time Analysis Software Programme (Light Cycler $^{\mathbb{R}} 480 \mathrm{SW}$ 1.5.0 SP4). The delta $\mathrm{Ct}(\Delta \mathrm{Ct})$ method was used for PCR single gene data analysis. The normalized $(\Delta \mathrm{Ct})$ for esp gene was calculated by subtracting the mean $\mathrm{Ct}$ of the $16 \mathrm{~S}$ rDNA housekeeping gene from the $\mathrm{Ct}$ of esp.

\section{Statistical analysis}

All biofilm assays were performed in triplicate. In CV quantitative analysis, the results were calculated by subtracting the median $\mathrm{OD}_{595}$ of the triplicates of the control (test broth and E. faecium isolate, without antibiotic) from the median $\mathrm{OD}_{595}$ of the triplicates of the sample. Statistical analysis was carried out by SPSS (version 18, USA). One-way ANOVA test was preferred for microtiter plate assay data. A $p$ value less than 0.05 was considered statistically significant. 


\section{Results and Discussion}

In this study, two E. faecium strains isolated from clinical samples were subjected. Isolates were investigated for resistance against seven antibiotics that are important to clinical treatment of Enterococcus infections (Table I). Both strains were resistant to AMP, KAN, STR, CHL, ERT, and VAN at high levels. In addition, E. faecium 95 strain showed resistance to GEN (MIC; 2,048 $\mu \mathrm{g} / \mathrm{ml}$ ), whereas E. faecium 84 strain was sensitive. According to this result, both strains were detected to exhibit multidrug resistance to clinically important antibiotics.

Biofilm producing $E$. faecalis OG1RF as a control strain was found sensitive to VAN only, whereas non-biofilm producer E. faecalis ATCC29212 was sensitive to all treated antibiotics except KAN (Table I). Considering this assay results, it can be indicated that the strains capable of producing biofilms are more resistant to antibiotics. MDR strains may have acquired antibiotic-resistant genes between bacteria that are present inside the biofilm structure causing to be inhospital adapted clones. In addition, the uncontrolled use of the most common antibiotics may have influenced the rise in prevalence of enterococcal infections in humans. Recent reports showed that E. faecium strains isolated from clinical samples had high degree of resistance to antibiotics [35-38]. In comparing the biofilm-forming strains $(\mathrm{BIO}+)$ with the non-biofilm-forming strains $(\mathrm{BIO}-)$, $\mathrm{BIO}+$ strains were high frequency resistant than $\mathrm{BIO}-$ strains in clinical E. faecium isolates [39]. This observation was also declared in some other studies conducted by Sindhanai et al. [40] and Bhardwaj et al. [41].These results support that the biofilm forming promotes the virulence profile to microorganisms [41].

The adherence ability of biofilm was determined by estimation of obtained OD values of $E$. faecium clinical isolates according to growth conditions including planktonic culture and different sub-MIC antibiotic dilutions-broth media supplemented with $1 \%$ glucose. After $48 \mathrm{~h}$ exposure to sub-MIC antibiotics, the biofilm exhibited for these antibiotics on the plates the highest adherence ratio, which was statistically significant difference $(p<0.05)$. The activities of antimicrobial agents were tested at sub-MICs against E. faecium 95, 84, and E. faecalis OG1RF biofilms are shown in Figures 1-3, respectively. According to biofilm induction with sub-MIC of antibiotics results; CHL, AMP, and GEN antibiotic values did not induce biofilm formation of E. faecium 95 strain. On the other hand, sub-MIC antibiotic values of inducing maximum biofilm formation in E. faecium 95 were MIC/128 of KAN ( $4 \mu \mathrm{g} / \mathrm{ml}), \mathrm{MIC} / 2$ of ERT $(512 \mu \mathrm{g} / \mathrm{ml}), \mathrm{MIC} / 32$ of VAN $(16 \mu \mathrm{g} / \mathrm{ml})$, and MIC/64 of STR $(32 \mu \mathrm{g} / \mathrm{ml})$ compared with control. The results proved that the different concentrations of each antibiotic promoted the maximum biofilm production. In addition, concentration of antibiotic decreased except ERT, 


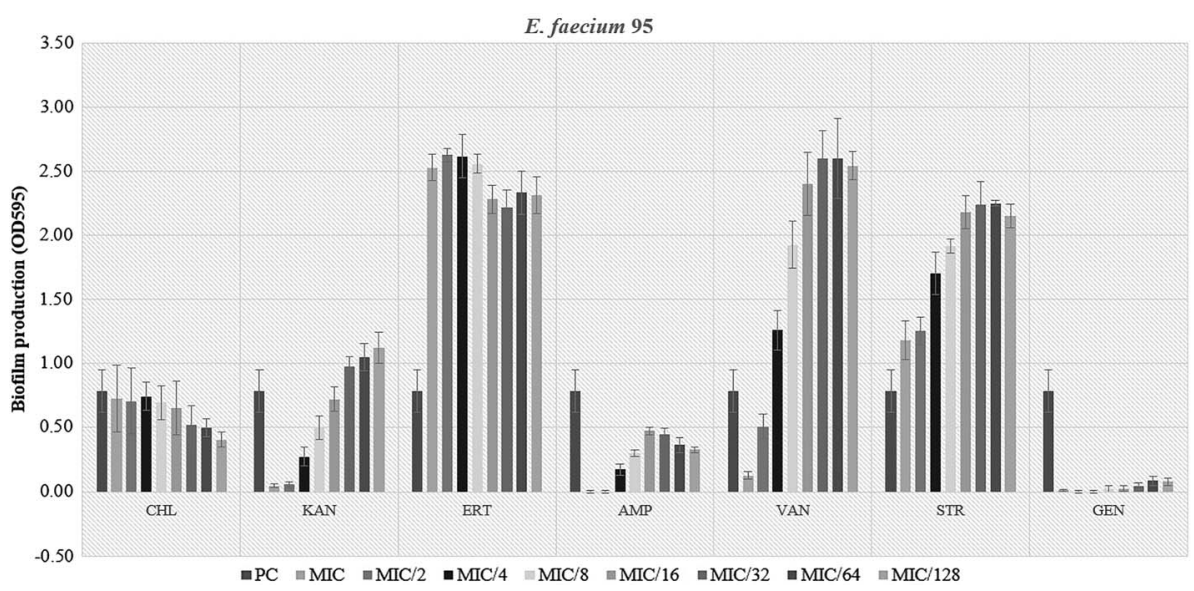

Figure 1. Biofilm production levels of E. faecium 95 strain following incubation with sub-MIC antibiotic levels. PC: positive control; CHL: chloramphenicol; KAN: kanamycin; ERT: erythromycin; AMP: ampicillin; VAN: vancomycin; STR: streptomycin; GEN: gentamicin

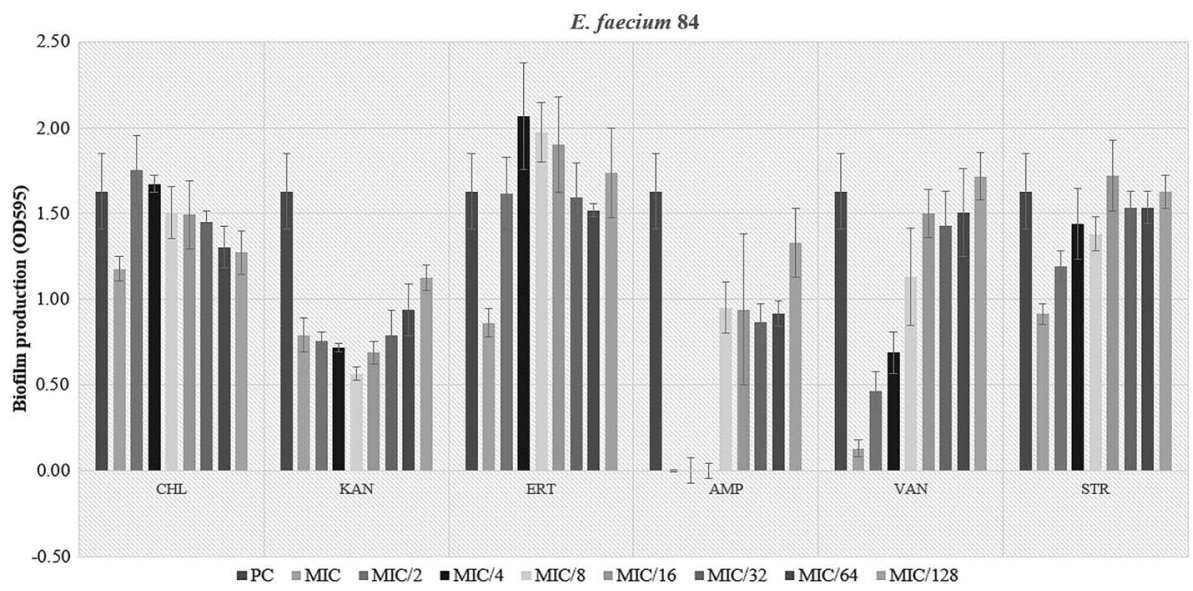

Figure 2. Biofilm production levels of E. faecium 84 strain following incubation with sub-MIC antibiotic levels. PC: positive control; CHL: chloramphenicol; KAN: kanamycin; ERT: erythromycin; AMP: ampicillin; VAN: vancomycin; STR: streptomycin

and the biofilm formation was also induced. Only the ERT was the cause of the increased biofilm formation on E. faecium 84 strain whose value was found to be $\mathrm{MIC} / 4(256 \mu \mathrm{g} / \mathrm{ml})$ whereas tested sub-MIC antibiotic values had any significant difference on biofilm formation of $E$. faecalis OG1RF. This study presented that 


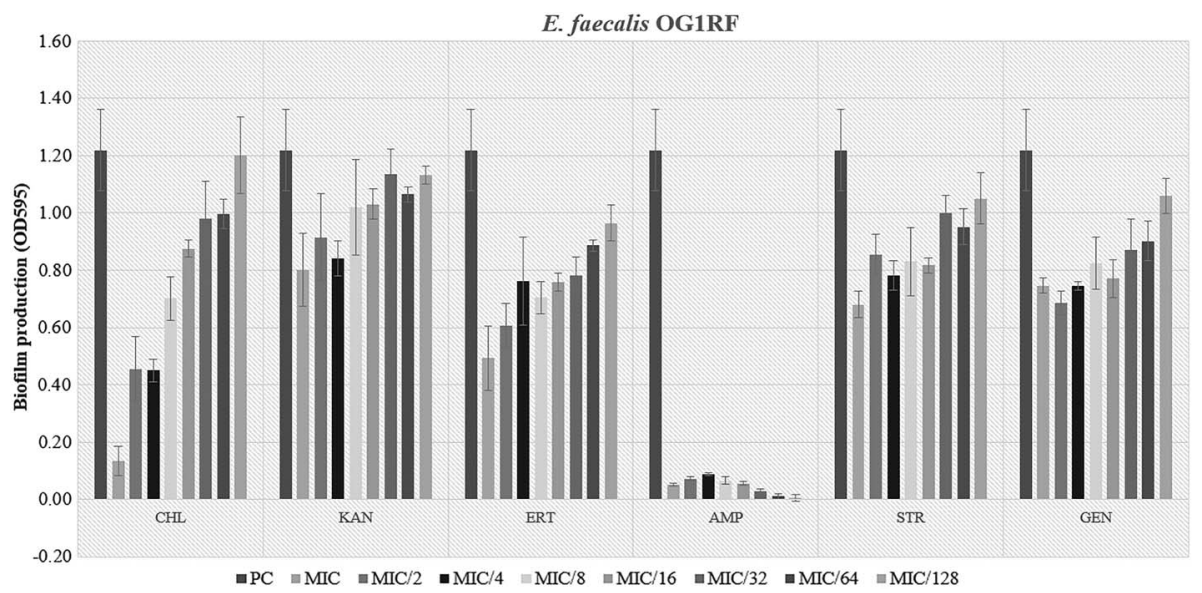

Figure 3. Biofilm production levels of E. faecalis OG1RF strain following incubation with sub-MIC antibiotic levels. PC: positive control; CHL: chloramphenicol; KAN: kanamycin; ERT: erythromycin; AMP: ampicillin; STR: streptomycin; GEN: gentamicin

strains formed different amounts of biofilm productivity. E. faecium 84 and E. faecalis OG1RF were more powerful biofilm producers compared with E. faecium 95. Strains producing high levels of biofilm in the absence of antibiotics may not form biofilm induction in the presence of sub-MIC antibiotic values [42], for instance, sub-MIC levels of azithromycin showed inhibition effect on $P$. aeruginosa biofilm formation [43]. The demonstration of differences in the formation of antibiotic-induced biofilms according to strains shows that a single model system cannot be established for treatment. In this case, it is necessary to conduct strain-based control.

Quantitive real-time PCR assay was used to evaluate the effect of sub-MIC of KAN, ERT, VAN, and STR on esp gene as one of the responsible genes on colonization of enterococci in selected strain E. faecium 95. Transcriptions of esp gene were strongly increased by $\mathrm{MIC} / 2$ of ERT $(512 \mu \mathrm{g} / \mathrm{ml}), \mathrm{MIC} / 32$ of VAN $(16 \mu \mathrm{g} / \mathrm{ml})$, and MIC/64 of STR $(32 \mu \mathrm{g} / \mathrm{ml})$. Although the MIC/128 of KAN ( $4 \mu \mathrm{g} / \mathrm{ml}$ ) induced biofilm formation, this concentration has no effect on the esp expression (Figure 4). As the similar results, Kafil et al. [31] showed, although expression of esp gene increased with GEN and VAN, it was reduced with ceftizoxime and AMP antibiotics. There are several virulence factors relating to biofilm, such as ace, esp, efaA, ebpA, and asal in Enterococci $[32,44]$. As based to this study, KAN-induced biofilm formation may not only depend on the induction of esp but also other virulence genes. Other components, such as extracellular DNA, may also be effective on the biofilm. 


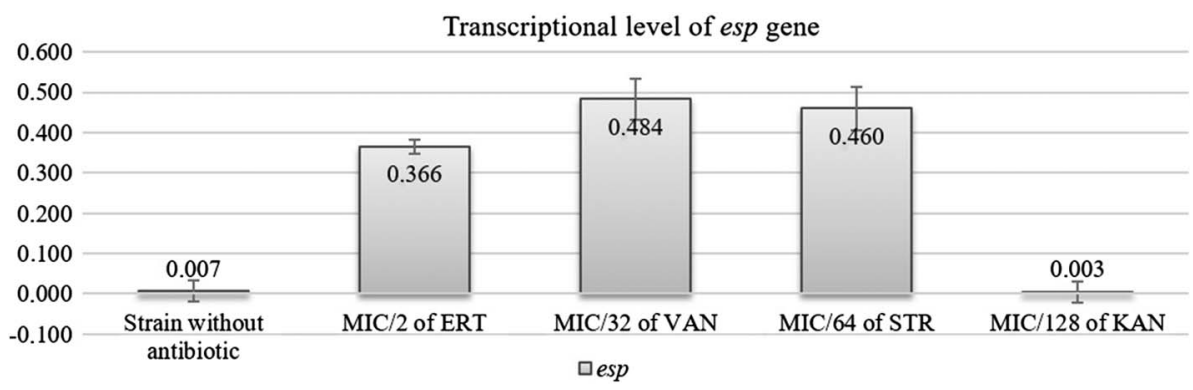

Figure 4. esp gene expression rate after antibiotic exposure in E. faecium 95

We showed that virulence gene expression patterns can be changed by exposure to antibiotics below MIC and there is no single mechanism of antibiotic-induced biofilm formation. There are limited studies about the role of antibiotics on enterococcal biofilm formation. More studies are needed to determine whether there is a relationship between biofilm inducibility and response to therapy. Genes responsible for biofilm formation should be investigated by knockout studies.

\section{Conclusions}

Antibiotic dosages in clinical treatment are generally chosen according to MICs of antibiotics against planktonic cells. Although MIC has been used as a gold standard to determine antimicrobial sensitivities of bacteria, the MIC value is not predictive of a particular antibiotic choosing in clinical efficacy because of the biofilm forming ability in bacteria. In addition, cells buried in deep within a biofilm matrix may be exposed to sub-MIC concentrations of antibiotics because of diffusion gradients. The data from our experiments showed that certain concentrations of chosen antibiotics stimulate biofilm production of clinically isolated E. faecium strain. Commonly using antibiotics as VAN in treatment of clinical enterococcal infections provokes the biofilm formation at low concentrations. We concluded that antibiotic concentrations for struggle with pathogens need to be designated carefully. In addition, induction of esp expression via sub-MICs of antibiotics may cause difficulties at accomplished by antibiotic therapy for eradicating persistent enterococcal infections associated with biofilms. Future studies as generation of mutant libraries will probably elucidate the mechanisms of biofilm induction by subMIC antibiotic levels. 


\section{Conflict of Interest}

The authors declare no conflict of interest.

\section{References}

1. Aka, S. T., Haji, S. H.: Sub-MIC of antibiotics induced biofilm formation of Pseudomonas aeruginosa in the presence of chlorhexidine. Braz J Microbiol 46, 149-154 (2015).

2. Weiner, L. M., Webb, A. K., Walters, M. S., Dudeck, M. A., Kallen, A. J.: Policies for controlling multidrug-resistant organisms in US healthcare facilities reporting to the National Healthcare Safety Network, 2014. Infect Control Hosp Epidemiol, 37, 1105-1108 (2016).

3. Mohamed, J. A., Huang, D. B.: Biofilm formation by enterococci. J Med Microbiol 56, 1581-1588 (2007).

4. Paganelli, F. L., Willems, R. J. L., Jansen, P., Hendrickx, A., Zhang, X., Bonten, M. J. M., Leavis, H. L.: Enterococcus faecium biofilm formation: Identification of major autolysin $\mathrm{Att}_{\mathrm{Efm}}$, associated Acm surface localization, and AtlA $\mathrm{Efm}_{\mathrm{Efm}}$-independent extracellular DNA release. mBio 4, e00154-13 (2013).

5. Shankar, V., Baghdayan, A. S., Huycke, M. M., Lindahl, G., Gilmore, M. S.: Infectionderived Enterococcus faecalis strains are enriched in esp, a gene encoding a novel surface protein. Infect Immun 67, 193-200 (1999).

6. Eaton, T. J., Gasson, M. J.: A variant enterococcal surface protein Esp (fm) in Enterococcus faecium; distribution among food, commensal, medical, and environmental isolates. FEMS Microbiol Lett 216, 269-275 (2002).

7. Shankar, N., Baghdayan, A. S., Gilmore, M. S.: Modulation of virulence within a pathogenicity island in vancomycin-resistant Enterococcus faecalis. Nature 417, 746-750 (2002).

8. Leavis, H., Top, J., Shankar, N., Borgen, K., Bonten, M., van Embden, J., Willems, R. J. : A novel putative enterococcal pathogenicity island linked to the esp virulence gene of Enterococcus faecium and associated with epidemicity. J Bacteriol 186, 672-682 (2004).

9. Toledo-Arana, A., Valle, J., Solano, C., Arrizubieta, M. J., Cucarella, C., Lamata, M., Amorena, B., Leiva, J., Penadés, J. R., Lasa, I.: The enterococcal surface protein, Esp, is involved in Enterococcus faecalis biofilm formation. Appl Environ Microbiol 67, 4538-4545 (2001).

10. Tendolkar, P. M., Baghdayan, A. S., Shankar, N.: The Nterminal domain of enterococcal surface protein, Esp, is sufficient for Esp-mediated biofilm enhancement in Enterococcus faecalis. J Bacteriol 187, 6213-6222 (2005).

11. Tendolkar, P. M., Baghdayan, A. S., Shankar, N.: Putative surface proteins encoded within a novel transferable locus confer a high-biofilm phenotype to Enterococcus faecalis. J Bacteriol 188, 2063-2072 (2006).

12. Diani, M., Esiyok, O. G., Ariafar, M. N., Yuksel, F. N., Altuntas, E. G., Akcelik, N.: The interactions between esp, fsr, gelE genes and biofilm formation and pfge analysis of clinical Enterococcus faecium strains. Afr J Microbiol Res 8, 129-137 (2014).

13. Pillai, S. K., Sakoulas, G., Eliopoulos, G. M., Moellering, R. C., Jr., Murray, B. E., Inouye, R. T.: Effects of glucose on fsr-mediated biofilm formation in Enterococcus faecalis. J Infect Dis 190, 967-970 (2004). 
14. Tendolkar, P. M., Baghdayan, A. S., Gilmore, M. S., Shankar, N.: Enterococcal surface protein, Esp, enhances biofilm formation by Enterococcus faecalis. Infect Immun $\mathbf{7 2}$, 6032-6039 (2004).

15. Sandoe, J. A., Witherden, I. R., Cove, J. H., Heritage, J., Wilcox, M. H.: Correlation between enterococcal biofilm formation in vitro and medical-device-related infection potential in vivo. J Med Microbiol 52, 547-550 (2003).

16. Dworniczek, E., Wojciech, L., Sobieszczanska, B., Seniuk, A.: Virulence of Enterococcus isolates collected in Lower Silesia (Poland). Scand J Infect Dis 37, 630-636 (2005).

17. Raad, I. I., Hanna, H. A., Boktour, M., Chaiban, G., Hachem, R. Y., Dvorak, T., Lewis, R., Murray, B. E.: Vancomycin-resistant Enterococcus faecium: Catheter colonization, esp gene, and decreased susceptibility to antibiotics in biofilm. Antimicrob Agents Chemother 49, 5046-5050 (2005).

18. Ramadhan, A. A., Hegedus, E.: Biofilm formation and esp gene carriage in enterococci. J Clin Pathol 58, 685-686 (2005).

19. Davies, J.: Are antibiotics naturally antibiotics? J Ind Microbiol Biotechnol 33, 496-499 (2006).

20. Romero, D., Traxler, M. F., López, D., Kolter, R.: Antibiotics as signal molecules. Chem Rev 111, 5492-5505 (2011).

21. Sengupta, S., Chattopadhyay, M. K., Grossart, H. P.: The multifaceted roles of antibiotics and antibiotic resistance in nature. Front Microbiol 4, 47 (2013).

22. Andersson, D. I., Hughes, D.: Microbiological effects of sub lethal levels of antibiotics. Nat Rev Microbiol 12, 465-478 (2014).

23. Balcázar, J. L., Subirats, J., Borrego, C. M.: The role of biofilms as environmental reservoirs of antibiotic resistance. Front Microbiol, 6, 1216 (2015).

24. Beaber, J. W., Hochhut, B., Waldor, M. K.: SOS response promotes horizontal dissemination of antibiotic resistance genes. Nature 427, 72-74 (2004).

25. Miller, C., Thomsen, L. E., Gaggero, C., Mosseri, R., Ingmer, H., Cohen, S. N.: SOS response induction by beta-lactams and bacterial defense against antibiotic lethality. Science 305, 1629-1631 (2004).

26. Maiques, E., Úbeda, C., Campoy, S., Lasa, I., Novick, R. P., Barbé, J., Penadés, J. R.: $\beta$-lactam antibiotics induce the SOS response and horizontal transfer of virulence factors in Staphylococcus aureus. Appl Environ Microbiol 188, 2726-2729 (2006).

27. Hoffman, L. R., D’Argenio, D. A., MacCoss, M. J., Zhang, Z., Jones, R. A., Miller, S. I.: Aminoglycoside antibiotics induce bacterial biofilm formation. Nature 436, 1171-1175 (2005).

28. Tezel, B. U., Akçelik, N., Yüksel, F. N., Karatuğ, N. T., Akçelik, M.: Effects of sub-MIC antibiotic concentrations on biofilm production of Salmonella Infantis. Biotechnol Biotechnol Equip 30, 1184-1191 (2016).

29. Balaji, K., Thenmozhi, R., Pandian, S. K.: Effect of subinhibitory concentrations of fluoroquinolones on biofilm production by clinical isolates of Streptococcus pyogenes. Indian J Med Res 137, 963-971 (2013).

30. Mlynek, K. D., Callahan, M. T., Shimkevitch, A. V., Farmer, J. T., Endres, J. L., Marchand, M., Bayles, K. W., Horswill, A. R., Kaplana, J. B.: Effects of low-dose amoxicillin on Staphylococcus aureus USA300 biofilms. Antimicrob Agents Chemother 60, 2639-2651 (2016). 
31. Kafil, H. S., Mobarez, A. M., Moghadam, M. F., Hashemi, Z. S., Yousefi, M.: Gentamicin induces efaA expression and biofilm formation in Enterococcus faecalis. Microb Pathog $\mathbf{9 2}$ 30-35 (2016).

32. Extremina, C. I., Costa, L., Aguiar, A. I., Peixe, L., Fonseca, A. P.: Optimization of processing conditions for the quantification of enterococci biofilms using microtitreplates. J Microbiol Methods 84, 167-173 (2011).

33. Baldassarri, L., Cecchini, R., Bertuccini, L., Ammendolia, M. G., Losi, F., Arciola, C. R., Montanaro, L., Di Rosa, R., Gherardi, G., Dicuonzo, G., Orefici, G., Creti, R.: Enterococcus spp. produces slime and survives in rat peritoneal macrophages. Med Microbiol Immunol 190, 113-120 (2001).

34. Diani (2016): Determination biofilm producing characteristics of Enterococcus strains isolated from Turkey originated cheese samples, $\mathrm{PhD}$ thesis, Ankara University Biotechnology Institute, Turkey.

35. Mengeloğlu, F. Z., Çakır, D., Terzi, H. A.: Comparison of resistance in isolates of Enterococcus faecalis and Enterococcus faecium. J Microbiol Infect Dis 1, 10-13 (2011).

36. Banerjee, T., Anupurba, S.: Prevalence of virulence factors and drug resistance in clinical isolates of Enterococci: A study from North India. J Pathogens 2015, 692612 (2015).

37. Kolli, H. R., Swarnalatha, K., Reddy, B. S., Singh, M., Kabra, V.: Isolation and identification of vancomycin resistance Enterococci from clinical specimens. Med Sci 6, 9-14 (2016).

38. Sundaram, M., Kavita, Y., Mohiddin, S. K.: Antibiogram of Enterococcal species isolated from clinical specimens in a tertiary care teaching hospital. J Evolution Med Dent Sci 5, 2955-2958 (2016).

39. Sieńko, A., Wieczorek, P., Majewski, P., Ojdana, D., Wieczorek, A., Olszańska, D., Tryniszewska, E.: Comparison of antibiotic resistance and virulence between biofilmproducing and non-producing clinical isolates of Enterococcus faecium. Acta Biochimica Pol 62, 859-866 (2015).

40. Sindhanai, V., Avanthiga, S. S., Chander, V. C. S.: Antibiotic susceptibility pattern of biofilm forming and biofilm non forming Enterococci species. IOSR J Dental Med Sci 15, 33-37 (2016).

41. Bhardwaj, S. B., Mehta, M., Sood, S., Sharma, J.: Biofilm formation by drug resistant Enterococci isolates obtained from chronic periodontitis patients. J Clin Diagn Res 11, DC01-DC03 (2017).

42. Kaplan, J. B.: Antibiotic-induced biofilm formation. Int J Artif Organs 34, 737-751 (2011).

43. Favre-Bonte, S., Kohler, T., Van Delden, C.: Biofilm formation by Pseudomonas aeruginosa: Role of the C4-HSL cell-to-cell signal and inhibition by azithromycin. J Antimicrob Chemother 52, 598-604 (2003).

44. Kafil, H. S., Mobarez, A. M., Moghadam, M. F.: Adhesion and virulence factor properties of Enterococci isolated from clinical samples in Iran. Indian J Pathol Microbiol 56, 238-42 (2013). 